Bull. Chem. Soc. Ethiop. 2017, 31(1), 17-30.

ISSN 1011-3924

(c) 2017 Chemical Society of Ethiopia and The Authors

Printed in Ethiopia

DOI: http://dx.doi.org/10.4314/bcse.v31i1.2

\title{
ASSESSMENT OF ESSENTIAL AND NON-ESSENTIAL METALS IN ETHIOPIAN TRADITIONAL FERMENTED ALCOHOLIC BEVERAGES
}

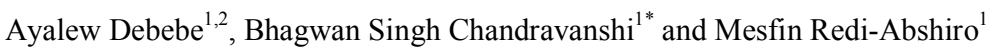 \\ ${ }^{1}$ Department of Chemistry, Addis Ababa University, P.O. Box 1176, Addis Ababa, Ethiopia \\ ${ }^{2}$ Department of Chemistry, Haramaya University, P.O. Box 138, Dire Dawa, Ethiopia
}

(Received July 16, 2016; revised May 4, 2017)

\begin{abstract}
Evaluation of the levels of essential and non-essential metal concentrations in Ethiopian traditional fermented alcoholic beverages (Tella, Tej, Birz, Korefe, Keribo and Borde) was conducted using atomic absorption spectrophotometer (AAS) after $\mathrm{HNO}_{3} / \mathrm{H}_{2} \mathrm{O}_{2}$ digestion process. A total of 10 bulk samples were collected randomly from vending houses at five different sub-cities of Addis Ababa, the capital city of Ethiopia (Lideta-Kolfe, Bole-Kirkose, Yeka-Gullele, Arada-Addis Ketema and Akaki-Kaliti-Lafto) and from five nearby towns (Sebeta, Dukem, Sululta, Sendafa, and Burayu) of Oromia Regional State. The considered metals include: $\mathrm{Ca}, \mathrm{Mg}, \mathrm{Fe}, \mathrm{Zn}, \mathrm{Cd}, \mathrm{Cr}, \mathrm{Cu}, \mathrm{Ni}, \mathrm{Pb}, \mathrm{Co}$ and $\mathrm{Mn}$ to ascertain their levels. With $88-96 \%$ recovery $\mathrm{Ca}, \mathrm{Mg}, \mathrm{Fe}, \mathrm{Zn}$, $\mathrm{Cu}, \mathrm{Cd}, \mathrm{Pb}$ and $\mathrm{Mn}$ were detected at varying concentrations in the beverages, while $\mathrm{Co}, \mathrm{Ni}$ and $\mathrm{Cr}$ were below detection limits. All the beverages were rich in $\mathrm{Ca}, \mathrm{Mg}$ and $\mathrm{Zn}$. Among the trace metals found $\mathrm{Zn}$ was the first. The levels of the trace metals were generally low, and within statutory safe limits set by World Health Organization (WHO). Mineral concentrations were found to be significantly different among the beverages studied $(\mathrm{p}<0.05)$. The levels of metals in the Ethiopian fermented beverages were found comparable with the reported ones.
\end{abstract}

KEY WORDS: Ethiopian beverages, Traditional beverages, Fermented beverages, Essential elements, Nonessential elements

\section{INTRODUCTION}

Traditional alcoholic beverages are indigenous to a particular area and are prepared by the local people using old age techniques and locally available raw materials [1,2]; accordingly, different countries, including Ethiopia have various indigenous alcoholic beverages [3-7]. The most familiar traditional fermented beverages are: high alcoholic beers such as Tella and Korefe; low alcoholic beers such as Keribo, Buqri, Shameta, Borde and wine such as Tej made from honey $[8,9]$. Similarly, the most popular distilled beverage is Areke [8, 9].

Living organisms (including plants, animals and microorganisms) store and transport metals so as to get appropriate concentration for later uses in physiological reactions as well as a means of protection against the toxic effects of the metals [10]. Mineral elements play a critical role in building body tissues and regulating numerous physiological processes. They are thus essential constituents of enzymes and hormones; regulate a variety of physiological processes, and are required for the growth and maintenance of tissues and bones [10]. In contrast, essential elements at excessive levels and toxic metals may lead to severe effects that include enhance premature aging and cause oxidative damage [11], reduced growth and development, cancer, organ damage, nervous system damage, and in extreme cases, death [12-15]. Toxic metals such as $\mathrm{Cd}$ and $\mathrm{Hg}$ are known to impair kidney functions and reproductive capacity, cause hypertension, tumor and hepatic dysfunction; whereas $\mathrm{Pb}$ can cause renal failure, liver damage, impaired hearing or cause mental retardation and in women, a shortened gestation period [11]. However, unlike in commercial alcoholic products, the role of metals in promoting or degrading the quality of traditional alcoholic beverages is not well documented.

${ }^{*}$ Corresponding author. E-mail: bscv2006@yahoo.com 
Metals find their way into alcoholic beverages at different stages and through various sources including the raw materials [12, 16-19], type of brewing process and equipment $[12,16-$ $21]$, bottling $[12,16-20,22]$, aging/storage $[12,17-21]$ and adulteration $[16,20]$. The contents of metals in alcoholic beverages vary within a broad range [23]. It depends on types of raw materials used [19, 22], the metal content in soil [17, 19-22, 24, 25], the agrochemical treatments (use of pesticides or fertilizers) $[17,19,21,22,25]$, treatments during vinification [19-22, 24] and environment pollution including industrial and urban sewage [19, 24-26] and air born particulate matter [12]. Substances added during brewing such as hops, acids, bases, silica gel, dilution water, flavoring agents, additives, and stabilizers are potential sources of metal ions in the brewing process [27]. Process equipment is frequently a key source of metal ions in the final products. Bottling water and equipment may also introduce metals in beverages. Possible effects caused by metals during aging/storage stages are multiple [28].

The level of metals in alcoholic beverages is highly affected by two major factors; natural and anthropogenic (derived from human activities). Natural sources include soils, i.e. soil type (resulting from the weathering of the parent rocks), wind (especially sea breezes) and the raw materials (fruit/plants) from which the alcoholic beverage is made [29]. Anthropogenic sources may in turn be divided into three subgroups such as substances employed in agriculture (organic and mineral fertilizers, inorganic pesticides and others) [29], environmental pollutants (dust, smoke and vehicle exhaust fumes) [15] and processing chemicals and contact with machinery employed in the production of alcoholic beverage [29].

The concentration of metals in many alcoholic beverages can be a significant parameter affecting their consumption and conservation. This derives from the negative and positive effects caused directly or indirectly by the presence of metals. Negative effects include beverage spoilage and hazing, as well as sensorial and health consequences [14, 19, 30-33]. Minerals may generate irreversible turbidities in liquors; the formation of sediments is a long lasting process that may depend on the contents of all metals and substances present, the redox potential, $\mathrm{pH}$, and temperature. Another effect involves the influencing of key organoleptic properties by high concentrations of certain metals [34].

Positive effects include the removal of bad odors and tastes, participation in fermentative processes, provision of pathways for dietary intake of some essential minerals, and usefulness for authentication purposes [31, 35]. Some metals enhance the flavor of wine [36]. Key concentration ratios of $\mathrm{K}, \mathrm{Na}$, and $\mathrm{Ca}$ to $\mathrm{Cu}$ can speed up the fermentation kinetics of a solution composed of raisin extract and sucrose [36-38]. Another useful aspect of the presence of specific metals in alcoholic beverages involves their use in quality analysis and in authentication (fingerprinting) due to their typical stabilities [39, 40, 41].

Thus, the assessment of trace elements in products for human consumption (food and beverages) is of utmost importance to ensure and preserve the consumer's well-being, to maintain the quality of the product and its niche in the market, and for identification of the product's geographic origin and authenticity [29, 31].

Therefore, the determination of metals in environmental, biological, and food samples has attracted significant attention due to their essential or toxic nature [11]. Accordingly, the objectives of this study were to: (i) determine the concentration of selected metals in different

Ethiopian traditional alcoholic beverages, and (ii) compare and contrast various alcoholic beverages based on their metallic contents.

\section{EXPERIMENTAL}

\section{Reagents and chemicals}

Reagents used in the analysis were all analytical grades. $\mathrm{HNO}_{3}(69-72 \%)$ (Spectrosol, $\mathrm{BDH}$, England) and $\mathrm{H}_{2} \mathrm{O}_{2}(30 \%)$ (BDH Chemicals Limited, Poole, England) were used for the digestion of different fermented alcoholic beverage samples. Stock standard solutions 
containing $1000 \mathrm{mg} \mathrm{L}^{-1}$ in $2 \% \mathrm{HNO}_{3}$ of the metals (Ca, Mg, Fe, $\mathrm{Zn}, \mathrm{Mn}, \mathrm{Cu}, \mathrm{Cr}, \mathrm{Co}, \mathrm{Ni}, \mathrm{Cd}$, and $\mathrm{Pb}$ ) (Buck Scientific Puro-Graphic ${ }^{\mathrm{tm}}$ ) were used for preparation of calibration standards and in the spiking experiments. Working standard solutions were obtained by suitable dilution from stock solution. Distilled-deionized water was used throughout the experiment for sample preparation and dilution, and rinsing of apparatus prior to analysis.

\section{Apparatus and instruments}

A refrigerator (Samsung Hitachi, Japan) was used to keep the fermented alcoholic beverage samples till the analysis. $250 \mathrm{~mL}$ round bottomed flasks fitted with reflux condensers were used on Kjeldahl apparatus hot plate to digest the fermented alcoholic beverages samples. Flame atomic absorption spectrophotometers (Analytik Jena ZEEnit 700P, Germany) equipped with deuterium arc background connectors and hollow cathode lamps with air-acetylene flame was used for the analysis of the analyte metals ( $\mathrm{Ca}, \mathrm{Mg}, \mathrm{Cr}, \mathrm{Ni}, \mathrm{Cu}, \mathrm{Zn}, \mathrm{Cd}, \mathrm{Pb}, \mathrm{Mn}, \mathrm{Co}$ and $\mathrm{Fe}$ ) in the samples. A micropipette $(100-1000 \mu \mathrm{L})$ was used for the volume measurement of reagents and standards.

\section{Sampling}

The most popular Ethiopian traditional fermented beverages, Tej (honey wine), Tella (a malt beverage like beer), Borde, Birz (honey water drink), Korefe and Keribo were selected. A total of 10 bulk samples were collected randomly from vending houses at five different sub-cities (Lideta-Kolfe, Bole-Kirkose, Yeka-Gullele, Arada-Addis Ketema and Akaki-Kaliti-Lafto) of Addis Ababa, the capital city of Ethiopia and from five nearby towns (Sebeta, Dukem, Sululta, Sendafa, and Burayu) of Oromia Regional State. $150 \mathrm{~mL}$ of the beverages were taken from the three sites of the towns and woredas of Addis Ababa to prepare $450 \mathrm{~mL}$ bulk samples of each type. All the samples were collected using glass amber bottles. The prepared bulk samples of the beverages were kept in a refrigerator at $4{ }^{\circ} \mathrm{C}$ until the analysis time.

\section{Digestion of samples}

The digestion procedures were optimized by varying: (i) the ratio and amount of $\mathrm{HNO}_{3}$ and $\mathrm{H}_{2} \mathrm{O}_{2}$ added to the sample, (ii) the digestion time and (iii) the temperature required for the digestion. The procedures which consumed least amount of the reagents and lower time and temperature for the digestion, giving clear solution with no precipitate were considered as the optimum procedure. Based on these parameters, different optimization results for different beverages were obtained. Smaller amounts of reagents and lower temperature and time than the optimum parameters resulted in incomplete digestion of samples which were indicated by colored and unclear digest with precipitates. The optimized digestion procedures are indicated in Table 1.

Table 1. Optimized volume ratio, temperature and duration of time for digestion of some alcoholic beverages samples.

\begin{tabular}{|c|c|c|c|c|c|c|}
\hline S. No. & Sample types & $\begin{array}{c}\text { Sample } \\
\text { volume } \\
(\mathrm{mL})\end{array}$ & $\begin{array}{c}\text { Total volume, } \mathrm{mL} \\
(\text { reagent ratio })\end{array}$ & $\begin{array}{c}\text { Temperature } \\
\left({ }^{\circ} \mathrm{C}\right)\end{array}$ & $\begin{array}{c}\text { Time } \\
(\mathrm{min})\end{array}$ & Remark \\
\hline 1 & $\begin{array}{c}\text { Tella, Korefe, } \\
\text { Keribo }\end{array}$ & 10 & $4\left(2: 2, \mathrm{HNO}_{3}: \mathrm{H}_{2} \mathrm{O}_{2}\right)$ & 240 & 90 & $\begin{array}{c}\text { Clear solution with no } \\
\text { precipitate }\end{array}$ \\
\hline 2 & Tej, Birz & 10 & $8\left(4: 4, \mathrm{HNO}_{3}: \mathrm{H}_{2} \mathrm{O}_{2}\right)$ & 240 & 150 & $\begin{array}{c}\text { Clear solution with no } \\
\text { precipitate }\end{array}$ \\
\hline 3 & Borde & 10 & $6\left(3: 3, \mathrm{HNO}_{3}: \mathrm{H}_{2} \mathrm{O}_{2}\right)$ & 240 & 90 & $\begin{array}{c}\text { Yellowish solution } \\
\text { with no precipitate }\end{array}$ \\
\hline
\end{tabular}




\section{Method performance evaluation}

Method validation is the process used to confirm that the analytical procedure employed for a specific test is suitable for its intended use. Results from method validation can be used to judge the quality, reliability and consistency of analytical results; it is an integral part of any good analytical practice. The parameters: accuracy, precision, specificity, limit of detection and limit of quantification are used for method validation. In this study, precision of the results was evaluated by standard deviation of the results of the nine measurements, triplicate digestion and triplicate readings. The method detection limits for each metal were calculated from the standard deviation(s) of the replicate analysis of six blanks prepared by the optimized procedure: $\mathrm{MDL}=$ $3 \times \mathrm{S}$ of blank $[42,43]$.

\section{Recovery test}

The accuracy of the analytical procedure was investigated by spiking a suitable known amount of the analyte metals into a test portion of the sample having a known concentration of the analyte, and analyzing the spiked test portion along with the original sample. The recovery test for all samples was performed in triplicates.

Determination of the metals in alcoholic beverages samples by FAAS

Stock standard solutions containing $1000 \mathrm{mg} \mathrm{L}^{-1}$ in $2 \% \mathrm{HNO}_{3}$ of the metals, $\mathrm{Ca}, \mathrm{Mg}, \mathrm{Mn}, \mathrm{Fe}$, $\mathrm{Cu}, \mathrm{Zn}, \mathrm{Ni}, \mathrm{Co}, \mathrm{Pb}, \mathrm{Cd}$, and $\mathrm{Cr}$ were used for the preparation of calibration standards and in the spiking experiments. All the analyses were carried out using flame atomic absorption spectrophotometer at the wavelengths specific for each metal. For the preparation of calibration curve, a series of four working standards were prepared for each metal. The working standards were prepared daily from the intermediate standards, that were earlier prepared from the stock solutions $\left(1000 \mathrm{mg} \mathrm{L}^{-1}\right)$.

\section{Statistical analysis}

Mean values obtained for the metals studied in the alcoholic beverage samples were compared by One-Way ANOVA at 95\% level using IBM SPSS statistics version 20; assuming that there were significant differences among them when the statistical comparison gives $p<0.05$.

\section{RESULTS AND DISCUSSION}

\section{Figures of merit}

The analytical wavelengths, the correlation coefficients, and the correlation equations of the calibration curves for the determination of metals in fermented alcoholic beverage samples by FAAS are given in Table 2. The correlation coefficients of all the calibration curves were $>$ 0.999 and these correlation coefficients showed that there was a very good correlation (relationship) between concentration and absorbance.

\section{Method validation}

To determine method detection limit, replicate analyses for 6 blank samples were performed and the pooled standard deviation of the six reagents blank was calculated. The detection limits were obtained by multiplying the pooled standard deviation of the reagent blank by three. The method detection limits of each metal for each sample type are given in Table 3. The method detection limits were generally comparable with that of the instrument for all samples. 
Table 2. Analytical wavelengths, working standard concentration, correlation coefficient and equation of the calibration curves for determination of metals using FAAS.

\begin{tabular}{|c|c|c|c|c|}
\hline Metals & $\begin{array}{c}\text { Wavelength } \\
(\mathrm{nm})\end{array}$ & $\begin{array}{c}\text { Concentration of working } \\
\text { standards }\left(\mathrm{mg} \mathrm{L}^{-1}\right)\end{array}$ & $\begin{array}{c}\text { Correlation } \\
\text { coefficient }(\mathrm{r})\end{array}$ & Equation for calibration curves \\
\hline $\mathrm{Ca}$ & 422.7 & $0.5,1.0,2.0,4,0$. & 0.9998 & $\mathrm{Y}=0.00201 \mathrm{X}+8.41 \times 10^{-5}$ \\
\hline $\mathrm{Mg}$ & 285.2 & $0.25,0.5,1,2.0$ & 0.9998 & $\mathrm{Y}=0.00595 \mathrm{X}-1.574 \times 10^{-4}$ \\
\hline $\mathrm{Cr}$ & 357.9 & $1.0,2.0,3.0,4.0$ & 0.9997 & $\mathrm{Y}=0.09698 \mathrm{X}+5.00 \times 10^{-4}$ \\
\hline $\mathrm{Ni}$ & 232 & $1.0,2.0,3.0,4.0$ & 0.9998 & $\mathrm{Y}=0.04318 \mathrm{X}-6.22 \times 10^{-3}$ \\
\hline $\mathrm{Cu}$ & 324.8 & $0.25,0.5,1.0,2.0$ & 0.9999 & $\mathrm{Y}=0.20258 \mathrm{X}-2.80 \times 10^{-4}$ \\
\hline $\mathrm{Zn}$ & 213.9 & $0.25,0.5,0.75,1$ & 0.9999 & $\mathrm{Y}=0.66746 \mathrm{X}-1.13 \times 10^{-3}$ \\
\hline $\mathrm{Cd}$ & 228.8 & $0.25,0.5,0.75,1$ & 0.9997 & $\mathrm{Y}=0.49265 \mathrm{X}-2.64 \times 10^{-3}$ \\
\hline $\mathrm{Pb}$ & 217 & $1.0,2.0,3.0,4.0$ & 0.9998 & $\mathrm{Y}=0.09786 \mathrm{X}+4.52 \times 10^{-3}$ \\
\hline $\mathrm{Co}$ & 279.5 & $0.25,0.5,1.0,2.0$ & 0.9994 & $\mathrm{Y}=0.00249 \mathrm{X}+2.40 \times 10^{-5}$ \\
\hline $\mathrm{Mn}$ & 240.7 & $0.25,0.5,1.0,2.0$ & 0.9998 & $\mathrm{Y}=0.0192 \mathrm{X}+4.80 \times 10^{-4}$ \\
\hline $\mathrm{Fe}$ & 248.3 & $0.5,1.0,1.5,3.0$ & 0.9997 & $\mathrm{Y}=0.00142 \mathrm{X}-2.08 \times 10^{-5}$ \\
\hline
\end{tabular}

\section{Recovery}

The accuracy of the analytical procedure was investigated by spiking $25 \%$ amount of the analyte metals recorded in the samples into a test portion of the sample having a known concentration of the analyte, and analyzing the spiked test portion along with the original sample. For elements having a result below detection limit, $0.25 \mathrm{mg} \mathrm{L}^{-1}$ was the amount added. The recovery results are presented in Table 3.

Table 3. Method performance for some Ethiopian fermented alcoholic beverages (Tella, Korefe, Keribo, Tej, Birz and Borde)

\begin{tabular}{|c|c|c|c|c|}
\hline Metal & LOD $\left(\mathrm{mg} \mathrm{L}^{-1}\right)$ & LOQ $\left(\mathrm{mg} \mathrm{L}^{-1}\right)$ & Recovery $(\%)$ & $\%$ RSD $(\mathrm{n}=6)$ \\
\hline $\mathrm{Ca}$ & $<0.025-0.27$ & $<0.075-0.81$ & $91-96$ & $0.1-7.6$ \\
\hline $\mathrm{Mg}$ & $<0.001-0.3$ & $<0.003-0.9$ & $88-92$ & $0.2-8.0$ \\
\hline $\mathrm{Zn}$ & $<0.01-0.15$ & $<0.03-0.45$ & $92-97$ & $0.2-3.2$ \\
\hline $\mathrm{Fe}$ & $<0.001-0.004$ & $<0.003-0.012$ & $89-96$ & $0.1-5.5$ \\
\hline $\mathrm{Cu}$ & $<0.02-<0.07$ & $<0.06-0.21$ & $88-92$ & $0.8-5.2$ \\
\hline $\mathrm{Cr}$ & $<0.05-0.09$ & $<0.15-0.27$ & $92-96$ & $0.3-8.8$ \\
\hline $\mathrm{Ni}$ & $<0.07-0.1$ & $<0.21-0.3$ & $88-92$ & $1.7-8.1$ \\
\hline $\mathrm{Cd}$ & $<0.005-0.01$ & $<0.015-0.03$ & $88-92$ & $1.0-9.4$ \\
\hline $\mathrm{Pb}$ & $<0.1-0.1$ & $<0.3-0.3$ & $92-96$ & $1.1-8.7$ \\
\hline $\mathrm{Co}$ & $<0.05-0.06$ & $<0.15-0.18$ & $90-96$ & $2.0-7.0$ \\
\hline $\mathrm{Mn}$ & $0.001-0.02$ & $<0.03-0.06$ & $92-96$ & $1.0-6.0$ \\
\hline
\end{tabular}

Determination of metals in Ethiopian traditional fermented alcoholic beverages samples by FAAS

The concentrations of $\mathrm{Ca}, \mathrm{Mg}, \mathrm{Cu}, \mathrm{Zn}, \mathrm{Ni}, \mathrm{Pb}, \mathrm{Cd}, \mathrm{Cr}, \mathrm{Mn}, \mathrm{Fe}$ and $\mathrm{Co}$ in the samples were determined by AAS using an air/acetylene flame at the wavelengths specific for each metal. To bring the concentration within the linearity range further dilution was done for $\mathrm{Ca}, \mathrm{Mg}$ and $\mathrm{Zn}$. All the analyses were carried out in triplicate. The summary of mean concentrations (mean \pm $\mathrm{SD}$ ) for the metals in different types of traditional alcoholic beverages are presented in Tables 4 -6 . 
Table 4. Mean concentrations $\left(\mathrm{mg} \mathrm{L}^{-1}\right)$ of metals in Tella samples.

\begin{tabular}{|c|c|c|c|c|c|c|c|}
\hline \multirow[t]{2}{*}{ S. No. } & \multirow[t]{2}{*}{ Samples } & \multicolumn{6}{|c|}{ Metal concentration $\left(\mathrm{mg} \mathrm{L}^{-1}\right)$} \\
\hline & & $\mathrm{Ca}$ & $\mathrm{Mg}$ & $\mathrm{Zn}$ & $\mathrm{Fe}$ & \multicolumn{2}{|c|}{$\mathrm{Cu}$} \\
\hline 1 & SEN & $24.1 \pm 12.8$ & $6.01 \pm 3.20$ & $25.6 \pm 5.40$ & $0.002 \pm 0.002$ & \multicolumn{2}{|c|}{$<0.03$} \\
\hline 2 & SEB & $83.3 \pm 3.20$ & $20.8 \pm 0.80$ & $4.49 \pm 2.00$ & $<0.001$ & \multicolumn{2}{|c|}{$<0.03$} \\
\hline 3 & SUL & $139 \pm 46.0$ & $34.8 \pm 11.5$ & $13.0 \pm 3.80$ & $0.001 \pm 0.003$ & \multicolumn{2}{|c|}{$<0.03$} \\
\hline 4 & DUK & $6.40 \pm 3.20$ & $1.60 \pm 0.80$ & $25.3 \pm 8.20$ & $0.011 \pm 0.002$ & \multicolumn{2}{|c|}{$<0.03$} \\
\hline 5 & BUR & $55.5 \pm 3.20$ & $13.9 \pm 0.80$ & $11.1 \pm 2.80$ & $0.004 \pm 0.002$ & \multicolumn{2}{|c|}{$<0.03$} \\
\hline 6 & LK & $168 \pm 37.0$ & $42.0 \pm 9.30$ & $2.90 \pm 2.00$ & $0.007 \pm 0.002$ & \multicolumn{2}{|c|}{$<0.03$} \\
\hline 7 & BK & $126 \pm 43.0$ & $31.5 \pm 10.8$ & $15.1 \pm 0.80$ & $0.007 \pm 0.002$ & \multicolumn{2}{|c|}{$<0.03$} \\
\hline 8 & $\mathrm{YG}$ & $849 \pm 51.0$ & $212 \pm 12.8$ & $9.40 \pm 6.00$ & $0.007 \pm 0.001$ & \multicolumn{2}{|c|}{$<0.03$} \\
\hline 9 & AAKT & $1.07 \pm 0.22$ & $0.80 \pm 0.06$ & $1.63 \pm 1.93$ & $0.021 \pm 0.001$ & \multicolumn{2}{|c|}{$<0.03$} \\
\hline 10 & $\mathrm{AKL}$ & $<0.09$ & $<0.1$ & $0.22 \pm 0.12$ & $0.008 \pm 0.001$ & \multicolumn{2}{|c|}{$<0.03$} \\
\hline S. No. & Samples & $\mathrm{Cr}$ & $\mathrm{Ni}$ & $\mathrm{Cd}$ & $\mathrm{Pb}$ & Co & $\mathrm{Mn}$ \\
\hline 1 & SEN & $<0.07$ & $8.53 \pm 3.00$ & $<0.01$ & $<0.1$ & $<0.06$ & $<0.02$ \\
\hline 2 & SEB & $<0.07$ & $1.00 \pm 0.80$ & $0.10 \pm 0.05$ & $0.43 \pm 0.05$ & $<0.06$ & $<0.02$ \\
\hline 3 & SUL & $<0.07$ & $4.25 \pm 1.20$ & $0.14 \pm 0.01$ & $0.44 \pm 0.04$ & $<0.06$ & $<0.02$ \\
\hline 4 & DUK & $<0.07$ & $2.32 \pm 1.00$ & $<0.01$ & $<0.1$ & $<0.06$ & $<0.02$ \\
\hline 5 & BUR & $<0.07$ & $0.23 \pm 0.02$ & $0.04 \pm 0.02$ & $0.31 \pm 0.05$ & $<0.06$ & $<0.02$ \\
\hline 6 & LK & $<0.07$ & $<0.1$ & $0.14 \pm 0.04$ & $0.65 \pm 0.20$ & $<0.06$ & $<0.02$ \\
\hline 7 & BK & $<0.07$ & $<0.1$ & $0.11 \pm 0.03$ & $0.48 \pm 0.10$ & $<0.06$ & $<0.02$ \\
\hline 8 & YG & $<0.07$ & $12.1 \pm 0.06$ & $0.13 \pm 0.10$ & $0.35 \pm 0.10$ & $<0.06$ & $<0.02$ \\
\hline 9 & AAKT & $<0.07$ & $<0.1$ & $0.05 \pm 0.04$ & $0.35 \pm 0.09$ & $<0.06$ & $<0.02$ \\
\hline 10 & AKL & $<0.07$ & $<0.1$ & $<0.01$ & $0.81 \pm 1.56$ & $<0.06$ & $<0.02$ \\
\hline
\end{tabular}

Sen $=$ Sendafa, Seb $=$ Sebeta, Sul $=$ Sululta, Duk $=$ Dukem, Bur $=$ Burayu, LK $=$ Lideta-Kolfe, BK $=$ BoleKirkose, $\mathrm{YG}=$ Yeka-Gullele, AAKT $=$ Arada-Addis Ketema, AKL $=$ Akaki-Kaliti-Lafto.

\section{Comparisons of the levels of the metals among Ethiopian fermented alcoholic beverages}

Among the beverages, Ca concentration was maximum in the Tella $\left(161 \mathrm{mg} \mathrm{L}^{-1}\right)$ and minimum in the Borde $\left(1.17 \mathrm{mg} \mathrm{L}^{-1}\right)$ and $\mathrm{Mg}$ content was also maximum in the Tella $\left(40.4 \mathrm{mg} \mathrm{L}^{-1}\right)$ and minimum in the Borde $\left(0.39 \mathrm{mg} \mathrm{L}^{-1}\right)$. Zn content was maximum in the Tella $\left(10.9 \mathrm{mg} \mathrm{L}^{-1}\right)$ and minimum in the Tej $\left(1.32 \mathrm{mg} \mathrm{L}^{-1}\right)$ while Fe content was maximum in the Korefe $\left(0.028 \mathrm{mg} \mathrm{L}^{-1}\right)$ and Borde $\left(0.028 \mathrm{mg} \mathrm{L}^{-1}\right)$ and minimum in the Tella $\left(0.008 \mathrm{mg} \mathrm{L}^{-1}\right) . \mathrm{Cu}$ content was maximum in the Borde $\left(1.15 \mathrm{mg} \mathrm{L}^{-1}\right)$ and minimum in the Birz $\left(0.038 \mathrm{mg} \mathrm{L}^{-1}\right)$, whereas it was below the detection limit in the Tella and Tej. Cd concentration was maximum in the Keribo $\left(2.37 \mathrm{mg} \mathrm{L}^{-1}\right)$ and minimum in the Birz $\left(1.54 \mathrm{mg} \mathrm{L}^{-1}\right)$, while it was below the detection limit in the Tej, Borde and Korefe. $\mathrm{Pb}$ content was maximum in the Keribo $\left(0.48 \mathrm{mg} \mathrm{L}^{-1}\right)$ and minimum in the Korefe $\left(0.13 \mathrm{mg} \mathrm{L}^{-1}\right)$ while it was below the detection limit in the Tej, Borde and Birz. Mn content was maximum in the Borde $\left(0.018 \mathrm{mg} \mathrm{L}^{-1}\right)$ and minimum in the Tej $\left(0.003 \mathrm{mg} \mathrm{L}^{-1}\right)$. Cr, $\mathrm{Ni}$ and $\mathrm{Co}$ contents were found below the detection limit in all the beverages except $\mathrm{Cr}$ in $T e j\left(0.10 \mathrm{mg} \mathrm{L}^{-1}\right)$ and $\mathrm{Ni}$ in Tella $\left(4.73 \mathrm{mg} \mathrm{L}^{-1}\right)$.

\section{Distribution pattern of the metals in Ethiopian fermented alcoholic beverages}

In general, the concentration of the metals in Tella samples was in the order: $\mathrm{Ca}>\mathrm{Mg}>\mathrm{Zn}>\mathrm{Ni}$ $>\mathrm{Pb}>\mathrm{Cd}>\mathrm{Fe}$. Metals such as $\mathrm{Cu}, \mathrm{Co}, \mathrm{Mn}$ and $\mathrm{Cr}$ in all samples were found below detection limits. In Tej (Table 5) like in Tella Ca (2.16 - $\left.11.8 \mathrm{mg} \mathrm{L}^{-1}\right)$ was the leading followed by $\mathrm{Mg}$ 
$\left(1.08-7.4 \mathrm{mg} \mathrm{L}^{-1}\right)$ and $\mathrm{Zn}\left(0.35-3.42 \mathrm{mg} \mathrm{L}^{-1}\right)$, respectively. In general, except $\mathrm{Ni}, \mathrm{Cu}, \mathrm{Cd}, \mathrm{Co}$ and $\mathrm{Pb}$ which were found below detection limits, the decreasing order of metals with average concentrations was, $\mathrm{Ca}>\mathrm{Mg}>\mathrm{Zn}>\mathrm{Cr}>\mathrm{Fe}>\mathrm{Mn}$. Likewise, the decreasing orders of metals in terms of their average concentrations were: for Birz $\mathrm{Ca}>\mathrm{Mg}>\mathrm{Cd}>\mathrm{Zn}>\mathrm{Fe}$; for Keribo $\mathrm{Ca}>$ $\mathrm{Mg}>\mathrm{Zn}>\mathrm{Cd}>\mathrm{Cu}>\mathrm{Pb}>\mathrm{Fe}$; for Korefe $\mathrm{Ca}>\mathrm{Zn}>\mathrm{Mg}>\mathrm{Cu}>\mathrm{Pb}>\mathrm{Fe}$ and for Borde $\mathrm{Zn}>$ $\mathrm{Ca}>\mathrm{Cu}>\mathrm{Fe}>\mathrm{Mn}$ (Table 6).

Among the Ethiopian fermented alcoholic beverages, Tella was found higher in $\mathrm{Ca}, \mathrm{Mg}, \mathrm{Zn}$ concentrations and was followed by Tej, Birz, Keribo Korefe and Borde, respectively. This is mostly by variation in composition of the raw materials. In most fermented alcoholic beverages, especially $\mathrm{Ni}, \mathrm{Cr}, \mathrm{Co}$ and $\mathrm{Mn}$ were below detection limits. This has an agreement with the ultra micro-elements composition $\left(<10 \mu \mathrm{g} \mathrm{L}^{-1}\right)$ of fermented beverages such as wine [44]. In Tej samples most of the metals especially heavy metals were below detection limits. This is mostly from its preparation pattern, especially hops or (Rhamnus prenoides (Gesho)) boiling with portion of must [45]. Toxic metals such as $\mathrm{Pb}$ and $\mathrm{Cd}$ were found in Tella, Korefe, and Keribo samples; on the other hand, they were not detected in Tej, Birz and Borde samples. Korefe was rich in $\mathrm{Fe}$ and $\mathrm{Cu}$ than Tella. This is because Korefe is semi-liquid; as a result, it has additional $\mathrm{Fe}$ and $\mathrm{Cu}$ which are found in the solid part. Likewise, Birz was rich in $\mathrm{Zn}, \mathrm{Cu}, \mathrm{Fe}$ and $\mathrm{Mn}$ than Tej. Since Birz has less fermentation time than Tej, therefore, the probability of these metals to be diminished by yeast is not significant. In addition, in the preparation of Birz, there is no treatment of the wort with hops-boiling. Birz, Korefe, Keribo and Borde were found rich in $\mathrm{Cu}$ whereas it was absent in Tella and Tej. This is mostly related with the action of yeast and the fermentation time required by the beverages. In general, the total metal content of Ethiopian fermented alcoholic beverages varied widely. This is because the metallic content in fermented alcoholic beverages are depending upon, the metallic content of raw materials, the effect of processes such as hop-boiling, fermentation and filtration [45].

Table 5. Mean concentrations $\left(\mathrm{mg} \mathrm{L}^{-1}\right)$ of metals in Tej samples.

\begin{tabular}{|c|c|c|c|c|c|c|c|}
\hline \multirow[t]{2}{*}{ S. No. } & \multirow[t]{2}{*}{ Samples } & \multicolumn{6}{|c|}{ Metal concentration $\left(\mathrm{mg} \mathrm{L}^{-1}\right)$} \\
\hline & & $\mathrm{Ca}$ & \multicolumn{2}{|c|}{\begin{tabular}{l|l}
$\mathrm{Mg}$ & $\mathrm{g}$
\end{tabular}} & $\mathrm{Zn}$ & $\mathrm{Fe}$ & $\mathrm{Cu}$ \\
\hline 1 & SEN & $11.8 \pm 3.15$ & \multicolumn{2}{|c|}{$5.9 \pm 1.58$} & $1.11 \pm 1.08$ & $0.018 \pm 0.001$ & $<0.07$ \\
\hline 2 & SEB & $2.16 \pm 2.72$ & \multicolumn{2}{|c|}{$1.08 \pm 1.36$} & $2.01 \pm 0.35$ & $0.013 \pm 0.002$ & $<0.07$ \\
\hline 3 & SUL & $14.8 \pm 1.07$ & \multicolumn{2}{|c|}{$7.4 \pm 0.54$} & $0.80 \pm 0.16$ & $0.022 \pm 0.002$ & $<0.07$ \\
\hline 4 & DUK & $10.4 \pm 0.58$ & \multicolumn{2}{|c|}{$5.2 \pm 0.29$} & $1.57 \pm 1.25$ & $0.014 \pm 0.004$ & $<0.07$ \\
\hline 5 & BUR & $10.7 \pm 0.79$ & \multicolumn{2}{|c|}{$5.35 \pm 0.40$} & $1.80 \pm 0.22$ & $0.013 \pm 0.002$ & $<0.07$ \\
\hline 6 & LK & $6.09 \pm 0.87$ & \multicolumn{2}{|c|}{$3.05 \pm 0.44$} & $0.35 \pm 0.21$ & $0.013 \pm 0.003$ & $<0.07$ \\
\hline 7 & BK & $9.33 \pm 0.68$ & \multicolumn{2}{|c|}{$4.67 \pm 0.34$} & $0.41 \pm 0.05$ & $0.011 \pm 0.002$ & $<0.07$ \\
\hline 8 & YG & $8.22 \pm 5.29$ & \multicolumn{2}{|c|}{$4.11 \pm 2.65$} & $1.17 \pm 0.63$ & $0.018 \pm 0.003$ & $<0.07$ \\
\hline 9 & AAKT & $8.26 \pm 1.90$ & \multicolumn{2}{|c|}{$4.13 \pm 0.95$} & $0.56 \pm 0.22$ & $0.013 \pm 0.003$ & $<0.07$ \\
\hline 10 & $\mathrm{AKL}$ & $7.59 \pm 0.60$ & \multicolumn{2}{|c|}{$3.80 \pm 0.30$} & & $0.015 \pm 0.006$ & $<0.07$ \\
\hline S. No. & Samples & $\mathrm{Cr}$ & $\mathrm{Ni}$ & $\mathrm{Cd}$ & $\mathrm{Pb}$ & \begin{tabular}{l|l|} 
Co \\
\end{tabular} & $\mathrm{Mn}$ \\
\hline 1 & SEN & $0.06 \pm 0.05$ & $<0.07$ & $<0.005$ & $<0$. & $<0.05$ & $<0.001$ \\
\hline 2 & SEB & $0.13 \pm 0.45$ & $<0.07$ & $<0.005$ & $<0$. & $<0.05$ & $<0.001$ \\
\hline 3 & SUL & $<0.09$ & $<0.07$ & $<0.005$ & $<0$. & $<0.05$ & $0.008 \pm 0.003$ \\
\hline 4 & DUK & $<0.09$ & $<0.07$ & $<0.005$ & $<0$. & $<0.05$ & $0.001 \pm 0.002$ \\
\hline 5 & BUR & $<0.09$ & $<0.07$ & $<0.005$ & $<0$. & $<0.05$ & $<0.001$ \\
\hline 6 & LK & $<0.09$ & $<0.07$ & $<0.005$ & $<0$. & $<0.05$ & $<0.001$ \\
\hline 7 & BK & $<0.09$ & $<0.07$ & $<0.005$ & $<0$. & $<0.05$ & $0.001 \pm 0.002$ \\
\hline 8 & YG & $<0.09$ & $<0.07$ & $<0.005$ & $<0$. & $<0.05$ & $0.001 \pm 0.002$ \\
\hline 9 & AAKT & $<0.09$ & $<0.07$ & $<0.005$ & $<0$. & $<0.05$ & $<0.001$ \\
\hline 10 & AKL & $<0.09$ & $<0.07$ & $<0.005$ & $<0$. & $<0.05$ & $0.002 \pm 0.001$ \\
\hline
\end{tabular}

Sen $=$ Sendafa, Seb $=$ Sebeta, Sul $=$ Sululta, Duk $=$ Dukem, Bur $=$ Burayu, LK $=$ Lideta-Kolfe, BK $=$ BoleKirkose, $\mathrm{YG}=$ Yeka-Gullele, AAKT $=$ Arada-Addis Ketema, AKL $=$ Akaki-Kaliti-Lafto.

Bull. Chem. Soc. Ethiop. 2017, 31(1) 
Table 6. Mean concentrations ( $\mathrm{mg} \mathrm{L}^{-1}$ ) of metals in the other (Birz, Keribo, Korefe, Borde) fermented beverage samples.

\begin{tabular}{|c|c|c|c|c|c|c|c|}
\hline \multirow[t]{2}{*}{ S. No. } & \multirow[t]{2}{*}{ Samples } & \multicolumn{6}{|c|}{ Metal concentration $\left(\mathrm{mg} \mathrm{L}^{-1}\right)$} \\
\hline & & $\mathrm{Ca}$ & $\mathrm{Mg}$ & $\mathrm{Zn}$ & \multicolumn{2}{|l|}{$\mathrm{Fe}$} & $\mathrm{Cu}$ \\
\hline \multicolumn{8}{|c|}{ Birz } \\
\hline 1 & Sample 1 & $48.6 \pm 7.57$ & $16.2 \pm 2.52$ & $1.39 \pm 0.19$ & \multicolumn{2}{|c|}{$0.001 \pm 0.002$} & $0.07 \pm 0.02$ \\
\hline 2 & Sample 2 & $44.5 \pm 5.21$ & $14.8 \pm 1.74$ & $1.56 \pm 0.72$ & \multicolumn{2}{|c|}{$0.012 \pm 0.002$} & $0.06 \pm 0.01$ \\
\hline 3 & Sample 3 & $45.5 \pm 7.14$ & $15.2 \pm 2.38$ & $1.70 \pm 0.64$ & \multicolumn{2}{|c|}{$0.015 \pm 0.001$} & $0.05 \pm 0.02$ \\
\hline 4 & Sample 4 & $53.1 \pm 3.69$ & $17.7 \pm 1.23$ & $0.89 \pm 0.86$ & \multicolumn{2}{|c|}{$0.021 \pm 0.001$} & $0.04 \pm 0.02$ \\
\hline \multicolumn{8}{|c|}{ Keribo } \\
\hline 5 & Sample 1 & $10.4 \pm 2.07$ & $3.48 \pm 0.69$ & $3.73 \pm 0.28$ & \multicolumn{2}{|c|}{$0.016 \pm 0.001$} & $0.18 \pm 0.02$ \\
\hline 6 & Sample 2 & $14.5 \pm 2.03$ & $4.82 \pm 0.68$ & $4.68 \pm 1.18$ & \multicolumn{2}{|c|}{$0.004 \pm 0.001$} & $0.68 \pm 0.08$ \\
\hline 7 & Sample 3 & $23.1 \pm 2.29$ & $7.71 \pm 7.43$ & $4.95 \pm 0.10$ & \multicolumn{2}{|c|}{$<0.001$} & $0.42 \pm 0.04$ \\
\hline 8 & Sample 4 & $5.32 \pm 0.72$ & $1.77 \pm 0.24$ & $3.13 \pm 0.36$ & \multicolumn{2}{|c|}{$0.021 \pm 0.001$} & $0.08 \pm 0.25$ \\
\hline 9 & Sample 5 & $5.57 \pm 0.36$ & $1.86 \pm 0.12$ & $2.36 \pm 0.16$ & \multicolumn{2}{|c|}{$0.024 \pm 0.002$} & $0.09 \pm 0.04$ \\
\hline 10 & Sample 6 & $1.03 \pm 0.48$ & $0.34 \pm 0.16$ & $2.75 \pm 0.21$ & \multicolumn{2}{|c|}{$0.026 \pm 0.003$} & $0.04 \pm 0.02$ \\
\hline \multicolumn{8}{|c|}{ Korefe } \\
\hline 11 & Sample 1 & $13.8 \pm 1.14$ & $4.61 \pm 0.38$ & $4.23 \pm 0.18$ & \multicolumn{2}{|c|}{$0.016 \pm 0.001$} & $0.21 \pm 0.04$ \\
\hline 12 & Sample 2 & $6.29 \pm 0.48$ & $2.10 \pm 0.16$ & $3.49 \pm 0.53$ & \multicolumn{2}{|c|}{$0.033 \pm 0.002$} & $0.28 \pm 0.06$ \\
\hline 13 & Sample 3 & $18.0 \pm 0.66$ & $6.00 \pm 0.22$ & $3.30 \pm 0.21$ & \multicolumn{2}{|c|}{$0.032 \pm 0.002$} & $0.27 \pm 0.02$ \\
\hline 14 & Sample 4 & $6.48 \pm 4.67$ & $2.16 \pm 1.56$ & $3.88 \pm 1.49$ & \multicolumn{2}{|c|}{$0.029 \pm 0.002$} & $0.24 \pm 0.06$ \\
\hline 15 & Sample 5 & $6.43 \pm 2.41$ & $2.14 \pm 0.80$ & $4.01 \pm 1.26$ & $0.027 \pm 0$ & 02 & $0.16 \pm 0.18$ \\
\hline 16 & Sample 6 & $11.7 \pm 2.61$ & $3.90 \pm 0.87$ & $2.39 \pm 0.12$ & $0.028 \pm 0$ & 03 & $0.37 \pm 0.14$ \\
\hline & & & & & & & \\
\hline 17 & Sample 1 & $1.27 \pm 0.67$ & $0.42 \pm 0.22$ & $3.78 \pm 0.05$ & $0.024 \pm 0$ & 03 & $3.16 \pm 0.05$ \\
\hline 18 & Sample 2 & $1.34 \pm 1.53$ & $0.45 \pm 0.51$ & $3.87 \pm 0.31$ & $0.033 \pm 0$ & 02 & $0.19 \pm 0.06$ \\
\hline 19 & Sample 3 & $0.91 \pm 0.55$ & $0.30 \pm 0.18$ & $3.74 \pm 0.03$ & $0.027 \pm 0$ & 01 & $0.11 \pm 0.07$ \\
\hline S. No. & Samples & $\mathrm{Cr}$ & $\mathrm{Ni}$ & $\mathrm{Cd}$ & $\mathrm{Pb}$ & $\mathrm{Co}$ & $\mathrm{Mn}$ \\
\hline & & & & & & & \\
\hline 1 & Sample 1 & $<0.09$ & $<0.07$ & $<0.005$ & $<0.1$ & $<0.05$ & $0.007 \pm 0.001$ \\
\hline 2 & Sample 2 & $<0.09$ & $<0.07$ & $<0.005$ & $<0.1$ & $<0.05$ & $0.016 \pm 0.002$ \\
\hline 3 & Sample 3 & $<0.09$ & $<0.07$ & $1.54 \pm 0.05$ & $<0.1$ & $<0.05$ & $0.022 \pm 0.003$ \\
\hline 4 & Sample 4 & $<0.09$ & $<0.07$ & $<0.005$ & $<0.1$ & $<0.05$ & $0.006 \pm 0.001$ \\
\hline & & & & & & & \\
\hline 5 & Sample 1 & $<0.07$ & $<0.1$ & $<0.01$ & $<0.1$ & $<0.06$ & $<0.02$ \\
\hline 6 & Sample 2 & $<0.07$ & $<0.1$ & $<0.01$ & $<0.1$ & $<0.06$ & $<0.02$ \\
\hline 7 & Sample 3 & $<0.07$ & $<0.1$ & $2.13 \pm 0.06$ & $<0.1$ & $<0.06$ & $<0.02$ \\
\hline 8 & Sample 4 & $<0.07$ & $<0.1$ & $2.08 \pm 0.03$ & $<0.1$ & $<0.06$ & $0.011 \pm 0.001$ \\
\hline 9 & Sample 5 & $<0.07$ & $<0.1$ & $1.05 \pm 0.05$ & $0.82 \pm 0.54$ & $<0.06$ & $<0.02$ \\
\hline 10 & Sample 6 & $<0.07$ & $<0.1$ & $4.20 \pm 4.40$ & $0.44 \pm 0.07$ & $<0.06$ & $<0.02$ \\
\hline & & & & & & & \\
\hline 11 & Sample 1 & $<0.07$ & $<0.1$ & $<0.01$ & $0.35 \pm 0.11$ & $<0.06$ & $0.005 \pm 0.003$ \\
\hline 12 & Sample 2 & $<0.07$ & $<0.1$ & $<0.01$ & $0.19 \pm 0.04$ & $<0.06$ & $0.015 \pm 0.002$ \\
\hline 13 & Sample 3 & $<0.07$ & $<0.1$ & $<0.01$ & $0.18 \pm 0.03$ & $<0.06$ & $0.016 \pm 0.001$ \\
\hline 14 & Sample 4 & $<0.07$ & $<0.1$ & $<0.01$ & $0.03 \pm 0.01$ & $<0.06$ & $0.014 \pm 0.001$ \\
\hline 15 & Sample 5 & $<0.07$ & $<0.1$ & $<0.01$ & $0.04 \pm 0.04$ & $<0.06$ & $0.010 \pm 0.002$ \\
\hline 16 & Sample 6 & $<0.07$ & $<0.1$ & $<0.01$ & $0.04 \pm 0.01$ & $<0.06$ & $0.012 \pm 0.003$ \\
\hline & & & & & & & \\
\hline 17 & Sample 1 & $<0.05$ & $<0.07$ & $<0.005$ & $<0.1$ & $<0.05$ & $0.001 \pm 0.002$ \\
\hline 18 & Sample 2 & $<0.05$ & $<0.07$ & $<0.005$ & $<0.1$ & $<0.05$ & $0.023 \pm 0.001$ \\
\hline 19 & Sample 3 & $<0.05$ & $<0.07$ & $<0.005$ & $<0.1$ & $<0.05$ & $0.029 \pm 0.002$ \\
\hline
\end{tabular}


Comparison of the levels of metals in Ethiopian fermented alcoholic beverages with other alcoholic beverages

The levels of metals in Ethiopian traditional fermented beverages (this study) were compared with the levels of metals in Nigerian beer [19], Ethiopian wines [24], Romanian wines [32], Chianti (Italian) wines [46], beers from different country of origin (including British, Dutch, German, Norwegian, Polish, Spanish and Others) [47], Cretan wines and wine products from Greek [48], different African beverages (including coconut palm wine, bamboo wine, banana wine, kibuku, safari' lager, konyagi' gin, moonshine, komoni and wanzuki) commercially available in Tanazania [49] and Nigerian wines [50].

Calcium concentrations of $83-142 \mathrm{mg} \mathrm{L}^{-1}$ [46] and $28-37 \mathrm{mg} \mathrm{L}^{-1}$ [24] in wine and $4-142$ $\mathrm{mg} \mathrm{L}^{-1}$ [47] in beer have been reported. In comparison with the reports, except Borde $(0.91-$ $\left.1.34 \mathrm{mg} \mathrm{L}^{-1}\right)$ which is less and Tella $\left(<0.09-849 \mathrm{mg} \mathrm{L}^{-1}\right)$ that is higher; Korefe $(6.29-13.8 \mathrm{mg}$ $\left.\mathrm{L}^{-1}\right)$, Keribo $\left(1.03-23.1 \mathrm{mg} \mathrm{L}^{-1}\right)$, Tej $\left(2.16-14.8 \mathrm{mg} \mathrm{L}^{-1}\right)$ and Birz $\left(44.5-53.1 \mathrm{mg} \mathrm{L}^{-1}\right)$ are comparable and within the ranges. The mean concentrations of $\mathrm{Mg}$ in the examined samples were in: Tella $\left(<0.1-212 \mathrm{mg} \mathrm{L}^{-1}\right)$, Tej $\left(1.08-7.4 \mathrm{mg} \mathrm{L}^{-1}\right)$, Birz $\left(14.8-17.7 \mathrm{mg} \mathrm{L}^{-1}\right)$, Korefe $\left(2.10-4.61 \mathrm{mg} \mathrm{L}^{-1}\right)$, Keribo $\left(0.34-7.71 \mathrm{mg} \mathrm{L}^{-1}\right)$ and Borde $\left(0.30-0.45 \mathrm{mg} \mathrm{L}^{-1}\right) . \mathrm{Mg}$ concentrations of $73-219 \mathrm{mg} \mathrm{L}^{-1}$ [46] and $58-79 \mathrm{mg} \mathrm{L}^{-1}$ [24] in wine and $24-270 \mathrm{mg} \mathrm{L}^{-1}$ [47] in beer have been reported. In comparison with the reported concentrations of $\mathrm{Mg}$, the obtained concentration in Tella is found comparable whereas in the rest beverages were lesser. A wide range of $\mathrm{Zn}$ concentrations have been reported such as $0.2-31 \mathrm{mg} \mathrm{L}^{-1}$ [48], $0.81 \mathrm{mg} \mathrm{L}^{-1}$ [50], $0.18-0.55 \mathrm{mg} \mathrm{L}^{-1}$ [32] and $1.82-2.70 \mathrm{mg} \mathrm{L}^{-1}$ [24] in wine, $0.001-1.5 \mathrm{mg} \mathrm{L}^{-1}$ [47] and $0.08-$ $0.15 \mathrm{mg} \mathrm{L}^{-1}$ [19] in beer, $2.5-5.8 \mathrm{mg} \mathrm{L}^{-1}$ [49] in coconut palm wine, $1.03 \mathrm{mg} \mathrm{L}^{-1}$ [49] in bamboo wine, $3.5-14.2 \mathrm{mg} \mathrm{L}^{-1}$ [49] in komoni, $0.4-1.4 \mathrm{mg} \mathrm{L}^{-1}$ [49] in wanzuki, $1.7-3.0 \mathrm{mg} \mathrm{L}^{-1}$ [49] in banana brew and $0-0.3 \mathrm{mg} \mathrm{L}^{-1}$ [49] in moonshine. Zn obtained in Tella $\left(0.22-25.6 \mathrm{mg} \mathrm{L}^{-1}\right)$, Tej $\left(0.35-3.42 \mathrm{mg} \mathrm{L}^{-1}\right)$, Birz $\left(0.89-1.70 \mathrm{mg} \mathrm{L}^{-1}\right)$, Korefe $\left(2.39-4.01 \mathrm{mg} \mathrm{L}^{-1}\right)$, Keribo $(2.36-$ $\left.4.95 \mathrm{mg} \mathrm{L}^{-1}\right)$ and Borde $\left(3.74-3.87 \mathrm{mg} \mathrm{L}^{-1}\right)$ are in the range of wines $\left(0.175-31 \mathrm{mg} \mathrm{L}^{-1}\right)$ and comparable with in African beverages $\left(0-14.2 \mathrm{mg} \mathrm{L}^{-1}\right)$. However, the obtained $\mathrm{Zn}$ concentration in these beverages is higher than in beer $\left(0.001-1.5 \mathrm{mg} \mathrm{L}^{-1}\right)$. The mean concentrations of $\mathrm{Zn}$ in these categories of alcoholic beverages except in Tella are below the permissible limit of WHO, $15 \mathrm{mg} \mathrm{L}^{-1}$ [49].

$\mathrm{Cu}$ in Tella $\left(<0.03 \mathrm{mg} \mathrm{L}^{-1}\right)$, Tej $\left(<0.07 \mathrm{mg} \mathrm{L}^{-1}\right)$, Birz $\left(0.04-0.07 \mathrm{mg} \mathrm{L}^{-1}\right)$, Korefe $(0.16-$ $\left.0.37 \mathrm{mg} \mathrm{L}^{-1}\right)$, Keribo $\left(0.04-0.68 \mathrm{mg} \mathrm{L}^{-1}\right)$ and Borde $\left(0.11-0.19 \mathrm{mg} \mathrm{L}^{-1}\right)$ was found in this study. In the literature concentrations of $\mathrm{Cu} 0.2-1.4 \mathrm{mg} \mathrm{L}^{-1}$ [48], $0.15 \mathrm{mg} \mathrm{L}^{-1}$ [50], $0.14-0.93$ $\mathrm{mg} \mathrm{L}^{-1}$ [46], $0.24-0.98 \mathrm{mg} \mathrm{L}^{-1}$ [32] and $0.5-1.50 \mathrm{mg} \mathrm{L}^{-1}$ [24] in wine and $0.04-0.09 \mathrm{mg} \mathrm{L}^{-1}$ [19], and $0.008-0.8 \mathrm{mg} \mathrm{L}^{-1}$ [47] in beer, $0.3-1.2 \mathrm{mg} \mathrm{L}^{-1}$ [49] in coconut palm wine, $0.4 \mathrm{mg} \mathrm{L}^{-1}$ [49] in bamboo wine, $0.3-0.5 \mathrm{mg} \mathrm{L}^{-1}$ [49] in komoni, $0.04-0.2 \mathrm{mg} \mathrm{L}^{-1}$ [49] in wanzuki, 0.5 $0.8 \mathrm{mg} \mathrm{L}^{-1}$ [49] in banana brew and $0.1-31.2 \mathrm{mg} \mathrm{L}^{-1}$ [49] in moonshine have been reported. The obtained concentrations of $\mathrm{Cu}$ in Ethiopian fermented alcoholic beverages are found comparable and within the range in beer $\left(0.008-0.8 \mathrm{mg} \mathrm{L}^{-1}\right)$ and wine $\left(0.14-1.5 \mathrm{mg} \mathrm{L}^{-1}\right)$. And also, the $\mathrm{Cu}$ obtained in Ethiopian fermented alcoholic beverages is comparable with that found in African beverages, except in moonshine $\left(0.1-31.2 \mathrm{mg} \mathrm{L}^{-1}\right)$. In addition, except one sample of Borde $\left(3.16 \pm 0.05 \mathrm{mg} \mathrm{L}^{-1}\right)$ in all beverages the $\mathrm{Cu}$ obtained is less than the limit of WHO, $1.5 \mathrm{mg} \mathrm{L}^{-1}$ [49]. In comparisons with ND $-2.3 \mathrm{mg} \mathrm{L}^{-1}$ [48], $0.02 \mathrm{mg} \mathrm{L}^{-1}$ [50] and $0.18-0.20 \mathrm{mg} \mathrm{L}^{-1}$ [24] in wine, and $0.04-0.10 \mathrm{mg} \mathrm{L}^{-1}$ [19] and $<0.3 \mathrm{mg} \mathrm{L}^{-1}$ [47] in beer, though Ni obtained in Tella $\left(<0.1-12.5 \mathrm{mg} \mathrm{L}^{-1}\right)$ is higher, in the rest beverages which were found below detection limits, the reported data does not have a significance difference. In addition, the mean concentrations of $\mathrm{Ni}$ in most beverages were below $0.02 \mathrm{mg} \mathrm{L}^{-1}$, the permissible limit for Ni set by WHO [49]. In all investigated beverage samples, except in Tej $\left(<0.09-0.13 \mathrm{mg} \mathrm{L}^{-1}\right)$, the obtained $\mathrm{Cr}$ concentration range was below detection limits. In comparison with the reported $\mathrm{Cr}$ concentration ranges, $\mathrm{ND}-1.6 \mathrm{mg} \mathrm{L}^{-1}$ [48], $0.09 \mathrm{mg} \mathrm{L}^{-1}$ [50] and $\mathrm{ND}-0.19 \mathrm{mg} \mathrm{L}^{-1}$ [24] in wine 
and $0.17-0.34 \mathrm{mg} \mathrm{L}^{-1}[19]$ in beer, the obtained $\mathrm{Cr}$ concentration range in Tej is comparable. Also for other beverages Cr concentrations are comparable with $<0.02 \mathrm{mg} \mathrm{L}^{-1}$ [47] in beer. Relative to the WHO limit, $0.05 \mathrm{mg} \mathrm{L}^{-1}$ [49], all beverages were obtained below the limit. Cd in Tej, Borde and Keribo was below detection limits. These are in agreement with the reported $<$ $0.0008 \mathrm{mg} \mathrm{L}^{-1}$ [19] in beer, $0.002 \mathrm{mg} \mathrm{L}^{-1}$ [50] and ND [24] in wine and $<0.001 \mathrm{mg} \mathrm{L}^{-1}$ [49] in wanzuki. Whereas, in Tella, Birz and Korefe was $<0.01-0.14 \mathrm{mg} \mathrm{L}^{-1},<0.005-1.54 \mathrm{mg} \mathrm{L}^{-1}$ and $<0.01-4.20 \mathrm{mg} \mathrm{L}^{-1}$, respectively. These obtained data are comparable with the reported ND $-4.5 \mathrm{mg} \mathrm{L}^{-1}$ [48] in wine, $0.003-0.008 \mathrm{mg} \mathrm{L}^{-1}$ [19] and $0.0002-0.7 \mathrm{mg} \mathrm{L}^{-1}$ [47] in beer and African beverages such as $0-0.6 \mathrm{mg} \mathrm{L}^{-1}$ [49] in coconut palm, $0.08 \mathrm{mg} \mathrm{L}^{-1}$ [49] in bamboo wine, $0-0.1 \mathrm{mg} \mathrm{L}^{-1}[49]$ in komoni, $<0.03 \mathrm{mg} \mathrm{L}^{-1}$ [49] in banana brew and $0.03-0.10 \mathrm{mg} \mathrm{L}^{-1}$ [49] in moonshine. According to WHO the limit for Cd is $0.05 \mathrm{mg} \mathrm{L}^{-1}$ [49], the beverages are found safe, though some samples have higher values. $\mathrm{Pb}$ in Birz, Borde and Tej was below detection limits. This is comparable with the reported $\mathrm{Pb} 0.0008-0.03 \mathrm{mg} \mathrm{L}^{-1}$ [47] and $0.02-$ $0.04 \mathrm{mg} \mathrm{L}^{-1}$ [19] in beer, and $0.08 \mathrm{mg} \mathrm{L}^{-1}$ [50] and $0.05-0.09 \mathrm{mg} \mathrm{L}^{-1}$ [32] in wine. However, in Tella, Korefe and Keribo was obtained as $<0.1-0.81 \mathrm{mg} \mathrm{L}^{-1},<0.1-0.82 \mathrm{mg} \mathrm{L}^{-1}$, and $0.03-$ $0.35 \mathrm{mg} \mathrm{L}^{-1}$, respectively. The concentrations of $\mathrm{Pb}$ obtained in these beverages are comparable with the reported beverages contain, especially ND $-0.62 \mathrm{mg} \mathrm{L}^{-1}[48]$ and $0.14-0.25 \mathrm{mg} \mathrm{L}^{-1}$ [24] in wine, and $0-0.81 \mathrm{mg} \mathrm{L}^{-1}$ [49] in African beverages. $0.1 \mathrm{mg} \mathrm{L}^{-1}$ [49] is the WHO limit for $\mathrm{Pb}$. Tella, Korefe and Keribo have higher values than the limit, however, the other beverages have lesser values. In all of Ethiopian fermented beverages Co was found below detection limits. This is in agreement with the reported data ND - $0.091 \mathrm{mg} \mathrm{L}^{-1}$ [24] in wine and especially $<0.0008 \mathrm{mg} \mathrm{L}^{-1}$ [47] in beer. The Mn concentrations found in Tella, Tej, Birz, Korefe, Keribo and Borde were $<0.02 \mathrm{mg} \mathrm{L}^{-1},<0.001-0.008 \mathrm{mg} \mathrm{L}^{-1}, 0.006-0.022 \mathrm{mg} \mathrm{L}^{-1},<0.02-$ $0.011 \mathrm{mg} \mathrm{L}^{-1}, 0.005-0.016 \mathrm{mg} \mathrm{L}^{-1}$ and $0.001-0.029 \mathrm{mg} \mathrm{L}^{-1}$, respectively. In comparison with the concentrations of $\mathrm{Mn}$ reported, $\mathrm{ND}-2.3 \mathrm{mg} \mathrm{L}^{-1}$ [48] in wine and $0.03-0.8 \mathrm{mg} \mathrm{L}^{-1}$ [47] in beer, they are found comparable. But, they are found less than $1.25-1.8 \mathrm{mg} \mathrm{L}^{-1}$ [46] and $1.04-$ $1.88 \mathrm{mg} \mathrm{L}^{-1}$ [24] in wine. The concentrations of Fe, $0.6-12 \mathrm{mg} \mathrm{L}^{-1}$ [48], $5.53 \mathrm{mg} \mathrm{L}^{-1}$ [50], $1.2-$ $3.5 \mathrm{mg} \mathrm{L}^{-1}$ [46] and $1.42-3.16 \mathrm{mg} \mathrm{L}^{-1}$ [24] in wine, $0.23-0.56 \mathrm{mg} \mathrm{L}^{-1}$ [19] and $0.02-1.6 \mathrm{mg}$ $\mathrm{L}^{-1}$ [47] in beer and $0.2-115 \mathrm{mg} \mathrm{L}^{-1}$ [49] in African beverages were reported, respectively. The concentrations of Fe found in this study were in: Tella $\left(0.001-0.021 \mathrm{mg} \mathrm{L}^{-1}\right)$, Tej $(0.011-0.022$ $\left.\mathrm{mg} \mathrm{L}^{-1}\right)$, Birz $\left(0.001-0.021 \mathrm{mg} \mathrm{L}^{-1}\right)$, Korefe $\left(0.016-0.033 \mathrm{mg} \mathrm{L}^{-1}\right)$, Keribo $(<0.1-0.026 \mathrm{mg}$ $\left.\mathrm{L}^{-1}\right)$ and Borde $\left(0.024-0.033 \mathrm{mg} \mathrm{L}^{-1}\right)$. In all cases, the Ethiopian fermented beverages have showed comparable concentrations of $\mathrm{Fe}$ in comparison with the reported beverages types, particularly with beer. Again, the WHO limit for Fe is $1 \mathrm{mg} \mathrm{L}^{-1}$ [49], relative to this Fe in all the beverages were found below the limit.

In general, though, there was a difference with the reported ones for few exceptional, the levels of metals in Ethiopian traditional fermented alcoholic beverages were almost comparable with reported metal contents of different alcoholic beverages like wine, beer, and others. In addition, most of the beverages were found below the limits set by WHO, but for toxic metals, $\mathrm{Cd}$ and $\mathrm{Pb}$ some few samples have levels that exceeded the WHO limits.

\section{Statistical analysis}

Statistical analysis of data was made to verify whether there was a significant difference in metal contents between the six Ethiopian traditional fermented alcoholic beverage varieties analyzed. In the present study, the significance of variation within sample and between samples has been studied using one-way ANOVA and calculations were made using SPSS software.

No significant difference $(\mathrm{p}>0.05)$ at $95 \%$ confidence level was observed for $\mathrm{Ca}, \mathrm{Mg}, \mathrm{Cu}$ and $\mathrm{Mn}$ concentrations in all the beverages varieties analyzed. On the other hand, significance difference $(\mathrm{p} \leq 0.05)$ at $95 \%$ confidence level was observed for $\mathrm{Cd}, \mathrm{Fe}, \mathrm{Pb}$ and $\mathrm{Zn}$ concentrations in all the beverages varieties analyzed. For some metals, there was significant 
variation $(\mathrm{p} \leq 0.05)$ at $95 \%$ confidence level among some beverage varieties while no significant variation was observed among the remaining beverage varieties when pair-wise comparison was performed. Table 7 summarizes pair-wise comparison of each metal in each sample with the remaining sample types.

Table 7. One-way ANOVA results at $95 \%$ confidence interval for a pair-wise investigation between beverage varieties.

\begin{tabular}{|c|c|c|}
\hline Metals & $\begin{array}{l}\text { Sample type with no significant difference }(\mathrm{p} \geq 0.05) \text { at } \\
95 \% \text { confidence level }\end{array}$ & $\begin{array}{l}\text { Sample type with significant difference } \\
(p \leq 0.05) \text { at } 95 \% \text { confidence level }\end{array}$ \\
\hline $\mathrm{Zn}$ & $\begin{array}{l}\text { Tella and Borde, Tella and Korefe, Tella and Keribo,Tej } \\
\text { and Borde, Tej and Birz, Tej and Korefe, Tej and Keribo, } \\
\text { Borde and Birz, Borde and Korefe,Borde and Keribo, } \\
\text { Birz and Korefe, Birz and Keribo, Korefe and Keribo }\end{array}$ & Tella and Tej, Tella and Birz \\
\hline $\mathrm{Fe}$ & $\begin{array}{l}\text { Tej and Birz, Tej and Keribo, Borde and Korefe, Borde } \\
\text { and Keribo, Birz and Keribo, Korefe and Keribo, Tella } \\
\text { and Tej, Tella and Birz }\end{array}$ & $\begin{array}{l}\text { Tella and Keribo, Tella and Korefe, } \\
\text { Tella and Borde, Tej and Korefe, Tej } \\
\text { and Borde, Birz and Korefe, Birz and } \\
\text { Borde }\end{array}$ \\
\hline
\end{tabular}

Absence of significant difference in some mineral nutrients in beverage varieties indicates the presence of similarities in certain factors or variables such as composition of the raw materials. Similarly, presence of significant difference in concentration for some minerals indicates the differences in the sources of metals in the beverages. This is because the metallic content in fermented alcoholic beverages depends upon the metallic content of raw materials, the effect of processes such as hop-boiling, fermentation and filtration.

\section{CONCLUSIONS}

Traditional fermented alcoholic beverages of Ethiopia were investigated for their major, trace and toxic metallic contents. The results confirmed that metals concentrations in Ethiopian fermented beverages differ among samples of different types and also among samples of the same types because metals in beverages are derived from various raw materials, equipment and brewing processes. In terms of metallic content, the Ethiopian fermented alcoholic beverages were found comparable with beer, wine and African traditional beverages. Most metals in these beverages were below the WHO limits. However, for toxic metals $\mathrm{Cd}$ and $\mathrm{Pb}$ some samples have higher values than the limit set by WHO.

\section{ACKNOWLEDGEMENTS}

The authors express their gratitude to the Department of Chemistry, Addis Ababa University, Ethiopia, for providing the laboratory facilities. Ayalew Debebe is thankful to the Haramaya University, Ethiopia, for sponsoring his study.

\section{REFERENCES}

1. Abegaz, K.; Beyene, F.; Langsurd, T.; Narvhus, J.A. Indigenous processing methods and raw materials of Borde, an Ethiopian traditional fermented beverage. J. Food Technol. Afr. 2002, 7, 59-64.

2. Abawari, R.A. Indigenous processing methods and raw materials of Keribo: An Ethiopian traditional fermented beverage. J. Food Resour. Sci. 2013, 2, 13-20. 
3. Savchuk, S.A.; Vlasov, V.N.; Appolonova, S.A.; Arbuzov, V.N.; Vedenin, A.N.; Mezinov, A.B.; Grigor'yan, B.R. Application of chromatography and spectrometry to the authentication of alcoholic beverages. J. Anal. Chem. 2001, 56, 214-231.

4. Brereton, P.; Hasnip, S.; Bertrand, A.; Wittkowski, R.; Guillou, C. Analytical methods for the determination of spirit drinks. Trends Anal. Chem. 2003, 22, 19-25.

5. Fletcher, P.J.; Van Staden, J.F. Determination of ethanol in distilled liquors using sequential injection analysis with spectrophotometric detection. Anal. Chim. Acta 2003, 499, 123-128.

6. Cocciardi, R.A.; Ismail, A.A.; Sedman, J. Investigation of the potential utility of singlebounce attenuated total reflectance Fourier transform infrared spectroscopy in the analysis of distilled liquors and wines. J. Agric. Food Chem. 2005, 53, 2803-2809.

7. Dragone, G.; Mussatto, S.I.; Oliveira, J.M.; Teixeira, J.A. Characterization of volatile compounds in an alcoholic beverage produced by whey fermentation. Food Chem. 2009, $112,929-935$.

8. Debebe, G. Determination of ethanol level in beverages. MSc Thesis, Addis Ababa University, Addis Ababa, Ethiopia, 2006.

9. Yohannes, T.; Melak, F.; Siraj, K. Preparation and physicochemical analysis of some Ethiopian traditional alcoholic beverages. Afr. J. Food Sci. 2013, 7, 399-403.

10. Gebre, A.; Chandravanshi, B.S. Levels of essential and non-essential metals in Rhamnus prinoides (Gesho) cultivated in Ethiopia. Bull. Chem. Soc. Ethiop. 2012, 26, 329-342.

11. Iwegbue, C.M.A.; Ojelum, A.L.; Bassey, F.I. A survey of metal profiles in some traditional alcoholic beverages in Nigeria. Food Sci. Nutr. 2014, 2, 724-733.

12. Bekele, D.; Chandravanshi, B.S. Levels of essential and non-essential metals in Ethiopian ouzo. SINET: Ethiop. J. Sci. 2012, 35, 19-28.

13. Formicki, G.; Stawarz, R.; Greńl, A.; Muchacka, R. Cadmium, copper, lead and zinc concentrations in low quality wines and alcohol containing drinks from Italy, Bulgaria and Poland. J. Microbiol. Biotechnol. Food Sci. 2012, 1, 753-757.

14. Stroe, S.-G.; Gutt, G.; Gutt, S.; Poroch-Seritan, M.; Severin, T.-L.; Maiorescu, M. Studies on the influence of the technological process on copper content in alcoholic beverages. Metal. 2011, 5, 18-20.

15. Ofori, H.; Owusu, M.; Anyebuno, G. Heavy metal analysis of fruit juice and soft drinks bought from retail market in Accra, Ghana. J. Sci. Res. Rep. 2013, 2, 423-428.

16. Alves, V.N.; Borges, S.S.O.; Neto, W.B.; Coelho, N.M.M. Determination of low levels of lead in beer using solid-phase extraction and detection by flame atomic absorption spectrometry. J. Autom. Methods Manag. Chem. 2011, 1-6. doi:10.1155/2011/464102.

17. Tariba, B.; Kljakovic-Gaspic, Z.; Pizent, A. Estimation of copper intake in moderate wine consumers in Croatia. Arh. Hig. Rada Toksikol. 2011, 62, 229-234.

18. Carreon-Alvarez, A.; Valderrama, R.C.; Martínez, J.A.; Estrada-Vargas, A.; Gómez-Salazar, S.; Barcena-Soto, M.; Casillas, N. Corrosion of aluminum, copper, brass and stainless steel 304 in tequila. Int. J. Electrochem. Sci. 2012, 7, 7877-7887.

19. Ubuoh, E.A.; Comas, U.C.; Eze, E.C. Analysis of metal concentrations in selected canned beers consumed in Owerri Urban, Imo state, Nigeria. Eur. Int. J. Sci. Technol. 2013, 2, 3542.

20. Stafilov, T.; Karadjova, I. Atomic absorption spectrometry in wine analysis - A review. Maced. J. Chem. Chem. Eng. 2009, 28, 17-31.

21. Illuminati, S.; Annibaldi, A.; Truzzi, C.; Scarponi, G. Recent temporal variations of trace metal content in an Italian white wine. Food Chem. 2014, 159, 493-497.

22. Mena, C.M.; Cabrera, C.; Lorenzo, M.L.; Lopez, M.C. Determination of lead contamination in Spanish wines and other alcoholic beverages by flow injection atomic absorption spectrometry. J. Agric. Food Chem. 1997, 45, 1812-1815. 
23. Navarro-Alarcon, M.; Velasco, C.; Jodral, A.; Terrés, C.; Olalla, M.; Lopez, H.; Lopez, M.C. Copper, zinc, calcium and magnesium content of alcoholic beverages and by-products from Spain: Nutritional supply. Food Addit. Contam. 2007, 24, 685-694.

24. Woldemariam, D.M.; Chandravanshi, B.S. Concentration levels of essential and nonessential elements in selected Ethiopian wines. Bull. Chem. Soc. Ethiop. 2011, 25, 169-180.

25. Gebre, A. Level of essential and non-essential metals in Gesho (Rhamnus prinoides) cultivated in Ethiopia. MSc Thesis, Addis Ababa University, Addis Ababa, 2011.

26. Cabrera-Vique, C.; Teissedre, P.-L.; Cabanis, M.-T.; Cabanis, J.-C. Determination and levels of chromium in French wine and grapes by graphite furnace atomic absorption spectrometry. J. Agric. Food Chem. 1997, 45, 1808-1811.

27. Mayer, H.; Marconi, O.; Floridi, S.; Montanari, L.; Fantozzi, P. Determination of Cu(II) in beer by derivative potentiometric stripping analysis. J. Inst. Brew. 2003, 109, 332-336.

28. Pohl, P. Fractionation analysis of metals in dietary samples using ion exchange and adsorbing resins. Trends Anal. Chem.2007, 26, 713-726.

29. Riganakos, K.A.; Veltsistas, P.G. Comparative spectrophotometric determination of the total iron content in various white and red Greek wines. Food Chem. 2003, 82, 637-643.

30. Tuzen, M.; Soylak, M. Trace heavy metal levels in microwave digested honey samples from middle Anatolia, Turkey. J. Food Drug Anal. 2005, 13, 343-347.

31. Hernandez-Caraballo, E.A.; Avila-Gomez, R.M.; Capote, T.; Rivas, F.; Perez, A.G. Classification of Venezuelan spirituous beverages by means of discriminant analysis and artificial neural networks based on their $\mathrm{Zn}, \mathrm{Cu}$ and $\mathrm{Fe}$ concentrations. Talanta 2003, 60, 1259-1267.

32. Mihaela, A.; Dumitrescu, V.; Tănase, I.G.; Maria, P.; Nedelcu, R. The optimization of the methods for $\mathrm{Cu}, \mathrm{Zn}$ and $\mathrm{Pb}$ content determination in Romanian wines by AAS after dry or microwave mineralization. Rom. Biotechnol. Lett. 2009, 14, 4319-4325.

33. Doe, E.D.; Awua, A.K.; Gyamfi, O.K.; Bentil, N.O. Levels of selected heavy metals in wheat flour on the Ghanaian market: A determination by atomic absorption spectrometry. Am. J. Appl. Chem. 2013, 1, 17-21.

34. Salvo, F.; Pera, L.L.; Bella, G.D.; Nicotina, M.; Dugo, G. Influence of different mineral and organic pesticide treatments on $\mathrm{Cd}(\mathrm{II}), \mathrm{Cu}(\mathrm{II}), \mathrm{Pb}(\mathrm{II})$, and $\mathrm{Zn}(\mathrm{II})$ contents determined by derivative potentiometric stripping analysis in Italian white and red wines. J. Agric. Food Chem. 2003, 51, 1090-1094.

35. Ibanez, J.G.; Carreon-Alvarez, A.; Barcena-Soto, M.; Casillas, N. Metals in alcoholic beverages: A review of sources, effects, concentrations, removal, speciation, and analysis. $J$. Food Comp. Anal. 2008, 21, 672-683.

36. Esparza, I.; Salinas, I.; Santamaria, C.; Garcia-Mina, J.M.; Fernandez, J.M. Electrochemical and theoretical complexation studies for $\mathrm{Zn}$ and $\mathrm{Cu}$ with individual polyphenols. Anal. Chim. Acta 2005, 543, 267-274.

37. Akrida-Demertzi, K.; Koutinas, A.A. Effect of copper, potassium, sodium and calcium on alcoholic fermentation of raisin extract and sucrose solution. Dev. Food Sci. (Food Sci. Human Nutr.) 1992, 29, 475-489.

38. Pohl, P. What do metals tell us about wine? Trends Anal. Chem. 2007, 26, 941-949.

39. Guerrero, M.I.; Herce-Paglia, C.; Gonzalez, A.G.; Heredia, F.J.; Troncoso, A.M.; Camean, A.M. Mineral elements in wine vinegars made by traditional methods. Sci. Alim. 1996, 16, $143-149$.

40. Núñez, M.; Peña, R.M.; Herrero, C.; García-Martín, S. Analysis of some metals in wine by means of capillary electrophoresis: Application to the differentiation of Ribeira Sacra Spanish red wines. Analusis 2000, 28, 432-437. 
41. Kokkinofta, R.; Petrakis, P.V.; Mavromoustakos, T.; Theocharis, C.R. Authenticity of the traditional Cypriot spirit zivania on the basis of metal content using a combination of coupled plasma spectroscopy and statistical analysis. J. Agric. Food Chem. 2003, 51, 62336239.

42. Christian, G.D. Analytical Chemistry, 2nd ed., John Wiley and Sons, Inc: New York; 2004.

43. Miller, J.N.; Miller, J.C. Statistics and Chemometrics for Analytical Chemistry, 5th ed., Pearson Practice Hall: England; 2005.

44. Voica, C.; Deheleanu, A.; Pamula, A. Method validation for determination of heavy metals in wine and slightly alcoholic beverages by ICP-MS. J. Phys.: Conf. Ser. 2009, 182, 012036, DOI:10.1088/1742-6596/182/1/012036.

45. Hudson, J.R. Role of trace metals in brewing. J. Inst. Brew. 1959, 65, 321-330.

46. Tamasi, G.; Pagni, D.; Carapelli, C.; Justice, N.B.; Cini, R. Investigation on possible relationships between the content of sulphate and selected metals in Chianti wines. J. Food Compos. Anal. 2010, 23, 333-339.

47. Pohl, P. Determination and fractionation of metals in beer: A review. Food Addit. Contam. 2008, 25, 693-703.

48. Galani-Nikolakaki, S.; Kallithrakas-Kontos, N.; Katsanos, A.A. Trace element analysis of Cretan wines and wine products. Sci. Total Environ. 2002, 285, 155-163.

49. Mosha, D.; Wangabo, J.; Mhinzi, G. African traditional brews: How safe are they? Food Chem. 1996, 57, 205-209.

50. Onianwa, P.C.; Adetola, I.G.; Iwegbue, C.M.A.; Ojo, M.F.; Tella, O.O. Trace heavy metals composition of some Nigerian beverages and food drinks. Food Chem. 1999, 66, 275-279. 